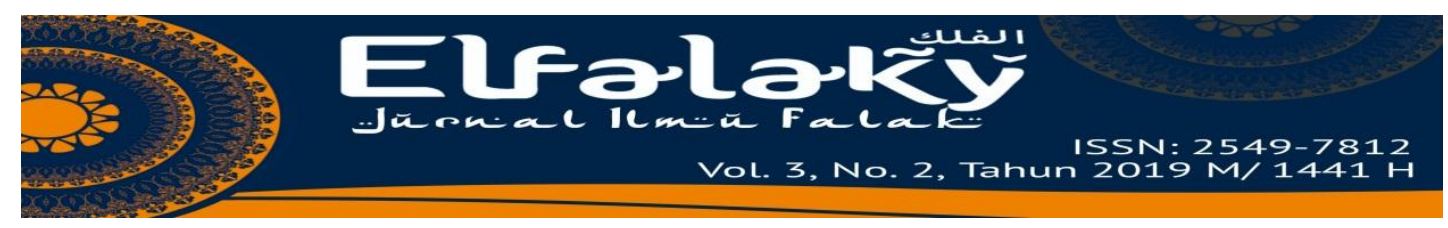

\title{
ASTROLABE; INSTRUMEN ASTRONOMI KLASIK \\ DAN KONTRIBUSINYA DALAM HISAB RUKYAT
}

\section{Fathor Rausi}

Mahasiswa S-2 Program Studi Ilmu Falak UIN Walisongo Semarang

Email: fathunnurelroznah829@gmail.com

\begin{abstract}
Abstrak
Kontribusi Astrolabe sebagai instrumen astronomi klasik tidak boleh dipandang sebelah mata. Peran dan kontribusinya cukup signifikan dalam perkembangan astronomi. Astrolabe secara umum berfungsi untuk menentukan waktu surya (solar time) dengan memanfaatkan fenomena alam, yaitu Matahari pada siang hari dan pengamatan bintang pada malam hari. Kehadiran Astrolabe dengan fungsinya tersebut sangat membantu aktivitas manusia sehari-hari dalam beberapa lini. Astrolabe mengalami modifikasi di tangan umat Islam, karena fungsi instrumen klasik ini selaras dengan syariat Islam, khususnya dalam penentuan awal waktu salat. Masuknya waktu salat dalam hukum Islam didasarkan kepada fenomena alam, seperti tergelincirnya Matahari (zawāl) sebagai tanda masuknya waktu salat zuhur.
\end{abstract}

Kata Kunci: Astrolabe, instrumen astronomi klasik dan hisab rukyat.

\section{A. Pendahuluan}

Astrolabe merupakan salah satu instrumen astronomi klasik tertua di dunia. Instrumen ini memproyeksikan bola langit di suatu tempat berbentuk piringan logam dengan lingkaran dan garis-garis rumit. Kehadiran Astrolabe yang mempunyai banyak fungsi turut mewarnai perkembangan sejarah peradaban manusia, khususnya dalam bidang astronomi. Astrolabe dimanfaatkan oleh manusia dalam menentukan waktu dan musim sejak awal kemunculannya. Tidak berlebihan kiranya, jika Astrolabe dianggap sebagai komputer pertama di dunia.

Kemunculan Astrolabe sendiri tidak terlepas dari legenda-legenda yang menjadi bumbu dalam sejarah perjalanannya. Konon, suatu hari ketika Ptolemaeus mengendarai unta, dia menjatuhkan bola celestialnya ke pasir. Unta yang ditungganginya menginjak bola tersebut hingga rata. Melihat kejadian tersebut, Ptolemaeus menyadari bahwa dia dapat memproyeksikan langit tiga dimensi pada cakram dua dimensi. Terlepas dari legenda yang menyelimuti kemunculan Astrolabe, instrumen ini merupakan buah dari 
perkembangan ilmu yang secara estafet diturunkan secara lintas generasi dan menjadi khazanah peradaban manusia.

Peradaban Islam juga turut andil dalam melanjutkan estafet perkembangan astronomi dengan hadirnya ilmu falak dalam disiplin keilmuan Islam. Astrolabe terus mengalami modifikasi dan penyempurnaan di tangan para ilmuwan muslim pada abad pertengahan, sehingga bermunculan Astrolabe dengan model baru. Semangat tersebut dipacu oleh fungsi utama Astrolabe, yaitu menentukan waktu berdasarkan posisi benda langit berkaitan erat dengan ibadah mahdah umat Islam, salat lima waktu, di samping juga dimanfaatkan untuk mengetahui waktu kiblat ( $r a \hat{s} d$ al-qiblah).

\section{B. Pembahasan}

\section{Definisi Astrolabe}

Astrolabe adalah instrumen astronomi klasik yang biasa digunakan untuk memperlihatkan posisi-posisi Matahari dan bintang-bintang untuk suatu waktu dan tempat tertentu. Astrolabe secara etimologi berasal dari bahasa Yunani "aster dan labio (labien)." Aster artinya bintang, sedangkan labio (labien) artinya pengintai atau pengukur. ${ }^{1}$ Dua kata tersebut kemudian digabung menjadi Astrolabe yang secara sederhana dapat dipahami bahwa Astrolabe adalah pengintai bintang atau alat bagi penggemar dan pemerhati bintang/astronomi.

Literatur klasik Arab menyebut Astrolabe dengan "usţurlāb” yang artinya alat untuk mengukur bintang (miqyās al-nujūm), penerjemahan yang disesuaikan dengan istilah dalam bahasa Yunani. Ada sebagian orang yang menganggap, kata usţurlāb berasal dari dua kata, yaitu usţur dan lāb. Usţur adalah bentuk plural dari satr dengan makna garis, sedangkan lāb adalah nama seorang laki-laki, yaitu anak Nabi Idris. ${ }^{2}$

Hamzah al-Asfihani memandang kata usţurlāb berasal dari bahasa Persia, yaitu istarahu yāb yang berarti mengambil bintang (akhżu alnujūm). Pendapat Hamzah al-Asfihani tersebut dibantah oleh Muhammad

${ }^{1}$ James E. Morrison, The Astrolabe, (DE USA: Janus Rehoboth Beach, 2007), h. 1.

${ }^{2}$ Abu Abdillah Muhammad al-Khawarizmi, Mafatih al-'Ulum, (Beirut: Dar al-Manahil, 2008), h. 205. 
al-Biruni. Menurut al-Biruni, usturlab disadur dari bahasa Yunani "astrolabio" yang artinya mir'ah al-syams/mirror of the Sun (cermin Matahari), karena instrumen tersebut memproyeksikan (cerminan) pergerakan Matahari dan benda-benda langit lainnya. ${ }^{3}$

Haji Khalifah dalam Kasyf al-Zunūn menjelaskan secara lebih detail pengertian dan fungsi Astrolabe. Menurutnya, Astrolabe adalah alat yang digunakan untuk mengetahui hal-ihwal posisi bintang-bintang dengan lebih mudah dan teliti, antara lain untuk mengetahui tinggi Matahari, mengetahui terbit dan terbenam, mengetahui azimut kiblat, mengetahui koordinat suatu tempat dan beberapa fungsi lainnya. ${ }^{4}$

Beberapa wacana di atas memberikan gambaran bahwa Astrolabe adalah sebuah instrumen astronomi yang digunakan untuk mengintai dan mengukur benda-benda langit, seperti Matahari dan bintang-bintang lainnya. Astrolabe sebagai alat pengintai bintang dapat digunakan untuk menemukan bintang-bintang dan mengukur ketinggiannya di langit. Adapun Astrolabe sebagai alat dalam astronomi, dapat digunakan untuk menentukan waktu surya (solar time) dengan membaca posisi Matahari pada siang hari dan suatu bintang tertentu pada malam hari.

\section{Astrolabe dalam Lintasan Sejarah}

\section{Asal-Usul Astrolabe}

Jika ditilik dari sejarahnya, sejarawan belum mengetahui secara pasti siapa penemu Astrolabe pertama kali, meskipun prinsip-prinsip Astrolabe sudah ditemukan sejak sebelum abad ke-2 SM. Beberapa literatur yang membahas Astrolabe memberikan informasi bahwa asal muasal instrumen kuno ini dari peradaban Yunani kuno. Hipparkhos diduga orang yang pertama kali menemukan Astrolabe. ${ }^{5}$ Dugaan tersebut dimentahkan dengan apa yang dilakukan oleh Eudoxus dari Cnidus (408-

\footnotetext{
${ }^{3}$ David A. King, The Origin of The Astrolabe According to The Medieval Islamic Sources, Journal for the History of Arabic Science, Vol. 5, 1981, h. 43.

${ }^{4}$ Haji Khalifah, Kasyf al-Zunūn 'an Asāmi al-Kutub wa al-Funūn, (Beirut: Dār Ihyā' alArabi, t.th), h. 106.

${ }^{5}$ Arwin Juli Rakhmadi Butar-Butar, Khazanah Astronomi Islam Abad Pertengahan, (Purwokerto: UM Purwokerto Press, 2016), 338.
} 
355 SM), seorang murid Plato membuat jam Matahari yang oleh beberapa sumber disebut "sarang laba-laba." Reputasi Eudoxus tersebut boleh disebut sebagai bentuk kasar Astrolabe. Oleh karena itu, Hipparkhos sebenarnya tidak menemukan Astrolabe, tetapi menyempurnakan teori proyeksi.

Konsep Astrolabe pertama kali sudah ada sejak sekitar abad ke-2 SM, namun secara fisik baru muncul pada abad ke-4 Masehi dan menjadi umum pada abad ke-7 Masehi. Ada juga yang mengatakan, Astrolabe secara fisik sudah muncul sekitar 26 SM sebagaimana disebutkan dalam karya-karya Marcus Vitruvius Pilo. Ia menggambarkan sebuah jam di Alexandria yang memiliki bintang-bintang pada bidang yang berputar di belakang bingkai kawat. ${ }^{6}$

Analisis Marcus berkaitan dengan apa yang ditulis oleh M. Khalid 'Ani dalam kitabnya, al-Usţurlāb. Menurut Khalid, Astrolabe pertama kali dikenal di Sekolah Alexandria. Aristarchus of Samos (310 SM - 230 SM) adalah orang yang pertama kali menggunakan alat tersebut untuk mengamati langit, sekitar 230 SM. Jejak Aristarchus diikuti oleh Hipparkhos setelah tahun $127 \mathrm{SM}^{7}$

Hipparkhos adalah tokoh yang pertama kali memperbaiki proyeksi pergerakan benda langit pada Astrolabe. Refleksi lengkap tentang proyeksi pergerakan benda langit pada Astrolabe pertama kali dilakukan oleh Claudius Ptolomeaus yang hidup di Alexandria pada tahun $127 \mathrm{M}^{8}{ }^{8}$ Tidak hanya itu, Ptolomeaus juga memperbaiki dasar-dasar geometri pergerakan benda langit pada Astrolabe sesuai dengan teori geosentrisnya.

Titik terang sejarah awal Astrolabe dimulai sejak Helenistik Alexandria, kemudian menyebar ke Utara, Bizantium dan ke Timur, dunia Islam. Astrolabe mulai dikenal oleh orang-orang India melalui dunia Islam. Pegetahuan tentang Astrolabe terus berkembang seiring

6 . James, The Astrolabe, 37.

${ }^{7}$ Khālid, al-Usturlāb, 1.

${ }^{8}$ Neugebauer, BY O., The Early History of The Astrolabe; Studies in Ancient Astronomy IX (1949), Journal Isis Chicago, doi: 10.1086/349045. 
perkembangan ilmu dalam dunia Islam, sehingga Astrolabe dikenal di dunia Barat, Afrika Utara dan Spanyol. Pada abad pertengahan, orangorang Latin yang melakukan perjalanan ke Spanyol kembali ke daerahnya dengan membawa pengetahuan tentang Astrolabe. ${ }^{9}$

Jauh sebelum itu, Astrolabe diduga sudah dikenal sejak masa Nabi Idris sebagaimana yang disebut dalam beberapa sumber Arab. Pendapat tersebut didasarkan pada nama Astrolabe tersebut berasal dari peristiwa yang dialami oleh anak Nabi Idris, yaitu Lab. Lab yang memiliki pengetahuan dalam bidang astronomi mempunyai kebiasaan bermain-main dan melukis di atas pasir. Suatu ketika, Lab menggambar sebuah garisgaris lingkaran yang putus-putus di atas pasir. Kemudian, salah satu saudaranya bertanya, man saţara haża? (siapa yang membuat garis-garis ini?). Saudaranya yang lain menjawab, saţarahu Lab (yang membuat garis-garis itu adalah Lab). Berawal dari kisah ini, maka alat tersebut disebut usturlab, nisbah kepada Lab dan aktivitas menggambarnya di atas pasir.

Ilmuwan yang juga menaruh perhatian besar terhadap Astrolabe adalah Saxon Iskandari yang hidup pada abad ke-4. Dia menulis buku tentang Astrolabe, al- 'Amal bi Żat al-Halaq dan al- 'Amāl bi al-Usţurlāb. Pembuatan Astrolabe berkembang pesat di Harran, dan dari sanalah tersebar ke dunia Islam. ${ }^{10}$

\section{Astrolabe di Dunia Islam}

Astrolabe kemungkinan besar dikenalkan di dunia Islam pada abad ke-8 dan 9 Masehi melalui terjemahan dari naskah-naskah kuno pada era Abbasiyah, khususnya masa pemerintahan Harun al-Rasyid (786-809 M) dan puteranya, al-Makmun (813-833 M). Di antara buku yang diterjemahkan adalah Al-Magest karya Ptolomeaus dan buku-buku lain tentang astronomi, termasuk literatur Astrolabe. Transliterasi karya-karya berbahasa Yunani ke bahasa Arab tersebut banyak dilakukan di Sabian

\footnotetext{
${ }^{9}$ Darin Hayton, An Introduction to the Astrolabe, ebook, 6.

${ }^{10}$ Khālid, al-Usturlāb, 1.
} 
kota Harran oleh orang-orang Yahudi dan Nasrani Nastorian. Tidak heran jika Harran menjadi pusat awal produksi Astrolabe.

Ilmuwan muslim yang pertama kali membuat Astrolabe di Timur Tengah adalah Abu Ishaq Muhammad bin Ibrahim al-Fazari (w.180 H./796 M.), ahli falak yang berasal dari Persia dan hidup pada masa dinasti Abbasiyah era Khalifah Abu Ja'far al-Mansur. Astrolabe karya al-Fazari merupakan Astrolabe lingkaran dengan tujuh lingkaran logam yang tersusun dan bergerak serta berfungsi sebagai alat pengukur layaknya Astrolabe datar. al-Fazari melengkapi alat yang dibuatnya itu dengan beberapa catatan tentang Astrolabe, yaitu al-'Amal bi al-Usţurlāb alMusaţ̦tah, al-A'māl bi al-Usţurlāb wa Huwa Żāt al-Halaq, Tuhfah alNāzir dan Bahjah al-Afkār. ${ }^{11}$

Pengetahuan tentang Astrolabe tersebar secara luas pada abad ke-9 dengan munculnya Ahmad bin Muhammad al-Farghani. Karya yang lahir dari tangannya terkait dengan Astrolabe adalah Şan'ah al-Usţurlāb wa alBurhān 'Alaih dan 'Amal al-Usţurlāb. Dua buku ini berisi tentang konstruksi Astrolabe dan instruksi lengkap untuk desainnya.

Pada abad ke-10, Muhammad al-Biruni datang dengan membawa karya monumentalnya Istî̀āb al-Wujūh al-Mumkinah fî Şan'ah alUsţurlāb. al-Biruni tercatat sebagai orang yang pernah menggunakan Astrolabe mekanik untuk menentukan kalender Bulan-Matahari. ${ }^{12}$

Pada abad 10 ini, Astrolabe dimodifikasi menjadi lebih sederhana untuk kepentingan navigasi. Astrolabe yang dibuat oleh ilmuwan muslim pada umumnya terdiri dari satu buah lubang pengintai dan dua buah piringan dengan skala derajat yang diletakkan sedemikian rupa untuk menyatakan ketinggian dan azimut benda langit. ${ }^{13}$

Astrolabe mulai dikenal di Eropa bersamaan dengan masa dinasti Umayah II di Cordova, Spanyol. Ibrahim bin Yahya al-Zarqali merupakan

\footnotetext{
${ }^{11}$ Haji, Kasyf..., 107. Lihat juga:

${ }^{12}$ Siti Tatmainul Qulub, Ilmu Falak dari Sejarah ke Teori dan Aplikasi, (Depok: PT RAJAGRAFINDO, 2017), 30.

${ }^{13}$ Siti, Ilmu Falak..., 30.
} 
orang yang sangat berjasa dalam mengenalkan Astrolabe di Bumi Andalusia. al-Zarqali yang oleh orang Eropa dikenal dengan Arzachel adalah seorang ahli matematika dan astronom legendaris Toledo, Spanyol. Arzachel berhasil mengkonstruksi sebuah instrumen astronomi yang dinamakan equatorium, sebuah instrumen penghitung bintang. Selain itu, ia juga mengembangkan instrumen lain yang dikenal dengan Saphaea, dalam bahasa Arab disebut Ŝfîhah atau Safäih (lempengan) yang merupakan bagian terpenting dari Astrolabe.

Saphaea merupakan Astrolabe universal berupa latitudeindependent. Jenis Astrolabe ini tidak tergantung pada koordinat tempat tertentu, sehingga dapat digunakan di sembarang wilayah. Astrolabe ini memiliki garis-garis untuk memudahkan aplikasi teori spherical astronomy, di mana garis-garis tersebut adalah data-data lintang suatu tempat.

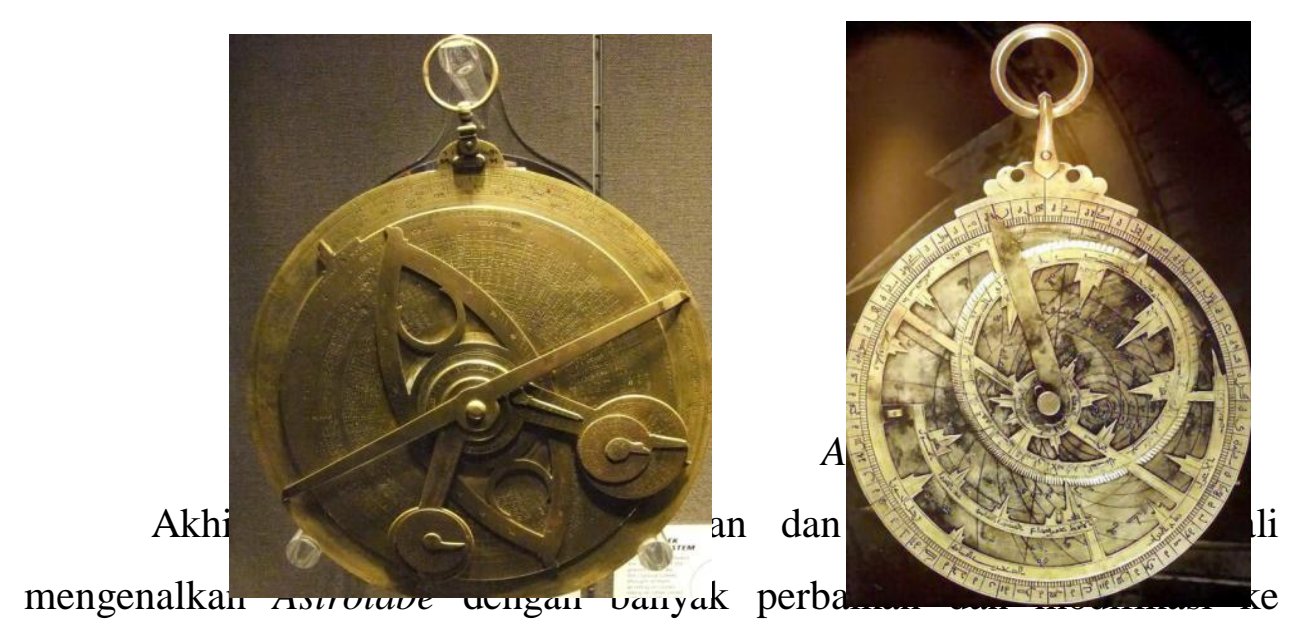

Eropa. Pada masa ini, Astrolabe benar-benar mengalami perkembangan yang sangat signifikan di Eropa. Alat ini kemudian digunakan di seluruh Eropa pada abad ke-13 hingga saat ini. Salah satu ilmuwan Islam pada abad ini yang memiliki karya tentang Astrolabe adalah Yusuf al-Mizzi dengan judul Risālah al-Mizzi fî al-Usţurlāb. al-Mizzi menguraikan dalam kitabnya tentang metode pengukuran ketinggian, menentukan bayangbayang, mengetahui deklinasi, mengetahui koordinat, mengetahui lingkaran waktu siang dan malam, menentukan waktu-waktu salat, 
mengetahui zenit kiblat, ketinggian sebuah tiang dan gunung, kedalaman sumur, luas sungai dan yang lainnya. ${ }^{14}$

Perkembangan Astrolabe di Indonesia, tidak terlepas dari peran Rukyatul Hilal Indonesia (RHI) yang dipelopori oleh Mutoha Arkanuddin. Rukyatul Hilal Indonesia memproduksi Astrolabe dengan modifikasi dan pengembangan dari Astrolabe kuno jenis Eropa. Astrolabe yang diproduksi oleh RHI terbuat dari bahan acrilic, ada juga yang dibuat dari bahan kayu, sedangkan peta langitnya didesain dengan komputer sesuai dengan lintang dan bujur yang dikehendaki. ${ }^{15}$

Astrolabe RHI dirancang khusus untuk wilayah Indonesia yang mayoritas berada di lintang selatan. Jenis Astrolabe RHI dilengkapi dengan jam rasd al-qiblah harian dengan mengacu pada posisi Matahari yang tergambar pada bagian depan Astrolabe. Mutoha Arkanuddin berencana untuk menambahkan ketinggian waktu asar pada Astrolabe yang dikembangkannya tersebut. ${ }^{16}$

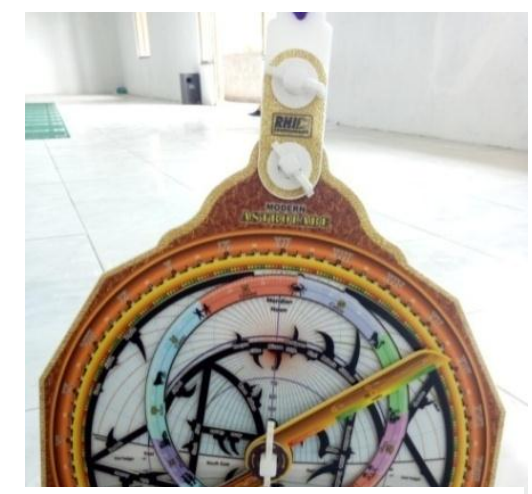

Astrolabe RHI (depan)

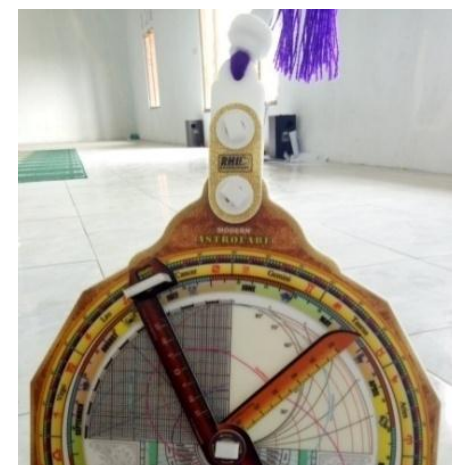

Astrolabe RHI (belakang)

\section{Macam-Ma}

Astrcunve ocvagar Minorumun asuonomi

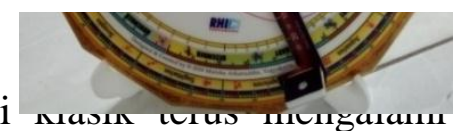

perkembangan dalam sejarah perjalanannya. Perkembangan Astrolabe dari masa ke masa melahirkan berbagai macam bentuk Astrolabe sesuai dengan

\footnotetext{
${ }^{14}$ Siti, Ilmu Falak..., 31.

${ }^{15}$ Hasil wawancara dengan Mutoha Arkanuddin di kediamannya, Jl. Gejayan Suropandan Yogyakarta pada 28 Oktober 2018, pukul 21:00 WIB.

${ }^{16}$ Hasil wawancara dengan Mutoha Arkanuddin di kediamannya, Jl. Gejayan Suropandan Yogyakarta pada 28 Oktober 2018, pukul 21:00 WIB.
} 
kebutuhan astronomis. Jika diklasifikasikan, macam Astrolabe mencapai 31 bentuk. Pembahasan ini hanya mencantumkan empat macam Astrolabe yang banyak dijumpai dan digunakan dalam dunia astronomi, yaitu:

a. al-Usţurlāb al-Musațţah/Planispheric Astrolabe

Planispheric Astrolabe merupakan jenis pertama yang diproduksi oleh orang Arab. Mayoritas modelnya berukuran kecil dan mudah dibawa. Biasanya, Astrolabe jenis ini terbuat dari logam yang terdiri dari cakram bundar dengan diameter antara 10-20 cm, memiliki lingkaran bernama al-habs yang terhubung ke cincin yang digunakan untuk menggantung Astrolabe. Planispheric Astrolabe menggambarkan bola langit pada lempengan dua dimensi dengan garis-garis dan lingkaran-lingkaran koordinat bola langit. Astrolabe semacam ini hanya berlaku untuk satu lokasi, sehingga bola langit yang diproyeksikan adalah langit yang sesuai dengan titik koordinat yang digunakan. ${ }^{17}$

b. al-Usţurlāb al-Kurawî/Spheric

Jenis Spherical Astrolabe lebin danulu muncul dari pada Planispheric Astrolabe. Jenis Astrolabe ini mudah digunakan karena terdiri dari dua lingkaran logam yang salah satunya menggambarkan zodiak, sedangkan satu lainnya menunjukkan azimut pergantian musim yang menggambarkan garis khatulistiwa. Selain dua lingkaran yang disebutkan, terdapat lingkaran yang ketiga pada jenis Astrolabe ini yang melintasi dua kutub zodiak. Lingkaran tersebut dapat digunakan untuk mengetahui bujur tempat. Pada lingkaran ke empat terdapat dua lubang yang dimanfaatkan untuk observasi Bulan, bintang, planet dan

${ }^{17}$ Khālid, al-Usţurlāb, 4. 
benda-benda langit lainnya yang dimungkinkan untuk dibidik. Bagian dalam Spherical Astrolabe terdapat semacam bola yang memproyeksikan Bumi.

Spherical Astrolabe memproyeksikan gerakan harian bola langit sehingga cocok digunakan untuk menentukan ketinggian bintang-bintang dan menentukan waktu. Astrolabe semacam ini biasa dimanfaatkan oleh awak kapal hingga abad ke-18. Di antara astronom yang membahas secara spesifik Spherical Astrolabe adalah Qusta bin Lukas (w. 300 H/912 M), Abul Abbas al-Nairizi (w. 310 H/922 M), Hasan bin Ali al-Marakisy (w. 660 H/1262 M) dan al-Biruni dalam karyanya Istî'āb al-Wujūh al-Mumkinah fî Şan'ah al-Usţurlāb. Jenis Astrolabe ini juga dikenal dengan al-Usţurlāb Żāt al-Halaq (Amillary Sphere). ${ }^{18}$

\section{c. al-Usţurlāb al-Syāmil/Universal Astrolabe}

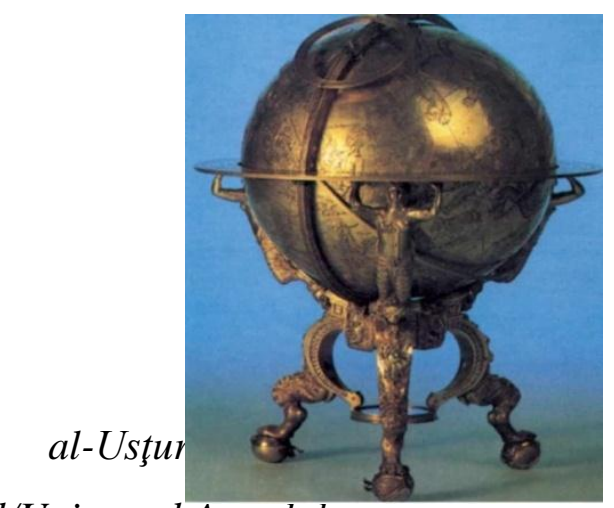

Astrolabe sebagaimana yang disebutkan hanya berfungsi untuk lokasi tertentu, karena platenya dibuat sesuai dengan lokasi pengamat. Jika hendak digunakan untuk lokasi yang lain, maka platenya harus diganti dengan plate lokasi yang bersangkutan. Tentu saja hal demikian menyulitkan pengguna Astrolabe karena harus gonta-ganti plate. Oleh karena itu, para pembuat Astrolabe berpikir untuk membuat Astrolabe dengan satu plate yang bisa digunakan untuk semua lokasi.

\footnotetext{
${ }^{18}$ Khālid, al-Uş̧urlāb, 4.
} 
Gagasan tentang Astrolabe universal bermula ketika ditemukannya sebuah plate horizontal yang cocok untuk semua lintang. Pada abad ke 5 Hijriah, Ali bin Khalaf al-Syakkaz, seorang sarjana Andalusia membuat plate yang dikenal dengan al-Syakkaziyah. Ide al-Syakkaz terinspirasi dari cahaya dari titik balik musim semi yang diproyeksikan pada level yang melewati titik balik musim panas dan dingin yang tegak lurus ke lingkaran langit.

Plate al-Syakkaziyah dikembangkan oleh Ibrahim bin Yahya yang dikenal dengan Ibn al-Zarqala (w. 493 H/1100 M). alZarqala membuat plate yang terdiri dari dua sketsa, yaitu untuk Ekuator dan Zodiak. Astrolabe karya al-Zarqala dikenal dengan Safä'ih al-Zarqala yang oleh orang-orang Eropa disebut Saphea Arzachelis.

\section{d. al-Usţurlāb al-Khațtî/Linear Astrolabe}

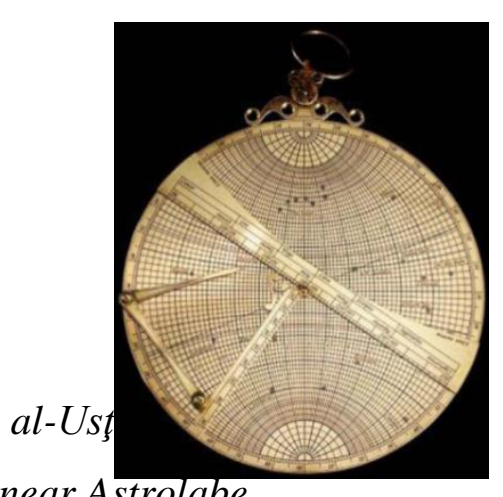

Gagasan linear Astrolabe dicetuskan oleh Syarafuddin alTusi (w. 606 H/1209 M), sehingga dikenal dengan 'ấā al-Ţūsî/tongkat Tusi. Al-Tusi memproyeksikan plate datar pada garis lurus dengan satu dimensi. Kreasi al-Tusi ini dianggap sebagai salah satu pencapaian dalam perabadan Islam, karena ia menggunakan konsep-konsep dimensi dan geometri yang tidak umum di kalangan praktisi sains pada abad pertengahan. ${ }^{19}$

Astrolabe jenis ini berbentuk tongkat dengan benang yang mengikatnya dan cocok digunakan untuk mengukur besaran sudut.

\footnotetext{
${ }^{19}$ Khālid, al-Usţurlāb, 10.
}

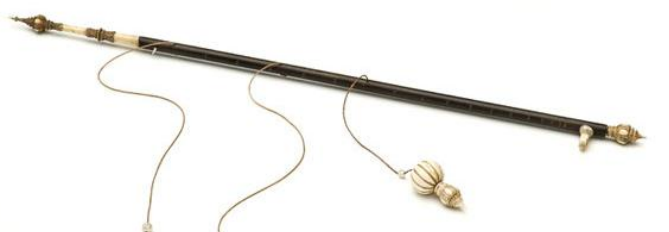


ELFALAKY: Jurnal Ilmu Falak

Vol. 3. Nomor 2. Tahun 2019 M / $1441 \mathrm{H}$

Linear Astrolabe dapat memudahkan dalam pengaplikasian Planispheric Astrolabe meskipun dengan akurasi rendah.

al-Usţurlāb al-Khațţî 


\section{Komponen Astrolabe}

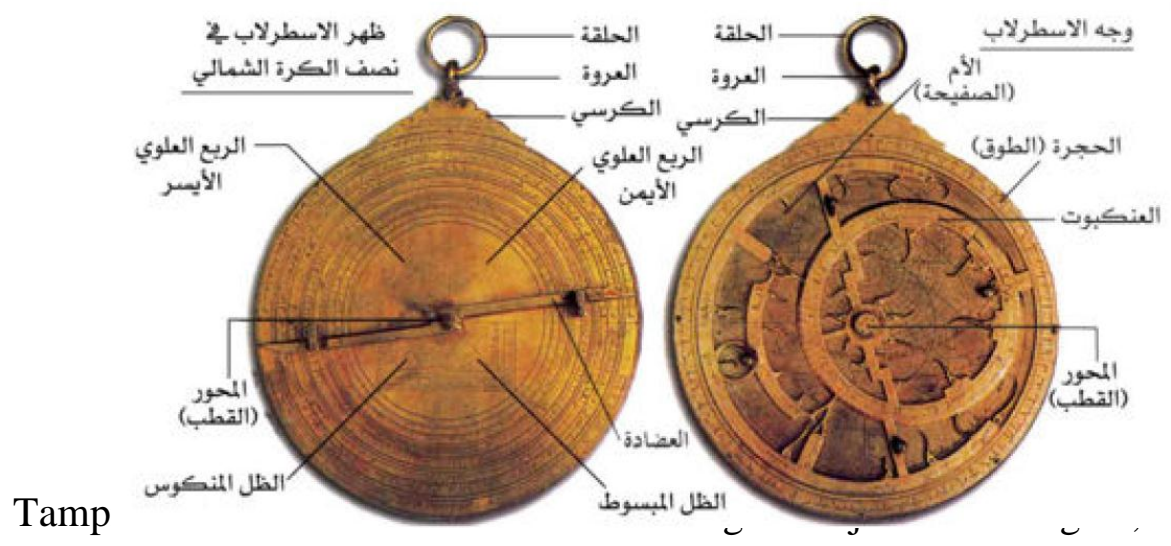

yaitu bagian depan dan bagian belakang. Komponen pada bagian depan Astrolabe adalah sebagai berikut ${ }^{20}$ :

a. al-Umm (Mater), adalah dinding lempengan yang berlubang di titik pusatnya yang berguna untuk menghubungkan lempengan-lempengan Astrolabe.

b. al-Muqantar (Almucantar), adalah lingkaran pada al-umm yang digunakan untuk menghitung ketinggian benda langit.

c. al-Ŝâihah (Tympan, Plates), adalah lempengan bulat berlubang dan rekah di sekitarnya serta sedikit menjorok yang memproyeksikan garis lintang pengamat, sehingga yang tergambar pada al- Safihah adalah proyeksi langit lokal pengamat. Safîhah memuat titik zenit, meridian, busur lingkaran ketinggian ufuk dan garis zenit langit dari titik pengamat.

d. al-'Ankabūt/al-Syabkah (Rete), adalah jaring berlubang dan sedikit menonjol yang didesain dapat bergerak bebas sehingga dapat menentukan posisi benda langit. al-'Ankabūt adalah proyeksi dari peta bintang karena ia memiliki lingkaran gerak di luar titik pusat yang menggambarkan lingkaran rasi-rasi bintang.

e. al-Misţarah/al-'Uqdah (Rule), adalah sebuah tongkat berbentuk seperti penggaris untuk menggerakkan bagian depan Astrolabe yang berfungsi

${ }^{20}$ Ibn al-Saffar, al-Amal bi al-Usturlab, (Mesir: al-Ma'had al-Misri: 1955), 38-43. Lihat juga: Siti, Ilmu Falak..., 35-37. 
mengukur sudut dan ketinggian Matahari pada siang hari dan bintang pada malam hari.

f. al-Kursiy (Throne), adalah bagian tetap berupa tonjolan yang melekat pada bagian atas al-umm yang terdapatlubang untuk menaruh tali yang berfungsi pegangan ketika Astrolabe digunakan untuk observasi. Lubang tersebut disebut al-'urwah (shackle), sedangkan talinya disebut al-halqah/al-'ulaqah (ring).

g. al-Hujrah (Limb), adalah bagian melingkar di sepanjang sisi al-umm, membungkus al-Ŝẩhah dan al-'ankabūt. al-Hujrah memuat garisgaris, angka dan huruf sebagai petunjuk skala, derajat dan jam.

h. al-Mihwar, adalah kutub yang menyatu dengan al-Ŝafihah dan al'ankabūt yang berlubang di titik tengahnya.

i. al-Fars/al-Hiŝān, adalah bagian dalam (tengah) Astrolabe yang bersambung dengan kutub al-mihwār.

Adapun komponen Astrolabe bagian belakang adalah sebagai berikut:

a. al-'Adladah (Alidade), adalah jarum ganda yang digunakan untuk membidik objek benda langit dan mengetahui ketinggiannya.

b. Daqāiq al-Tafāwut (Equation of Time), adalah kurva untuk penentuan perata waktu.

c. Mail al-Syams (Declination of the Sun), adalah kurva untuk mengetahui deklinasi Matahari.

d. Zîl al-Mabsūt (Umbra Recta), adalah bagian untuk perhitungan tangen dari suatu sudut.

e. Zîl al-Mankūs (Umbra Versa), adalah bagian untuk perhitungan cotangent dari suatu sudut.

f. al-Rub'u al-'Alawi, adalah kuadran sinus yang digunakan untuk perhitungan trigonometri yang sama seperti al-rub'u al-mujayyab.

\section{Kontribusi Astrolabe dalam Hisab dan Rukyat}

Astrolabe sebagai instrumen memberikan kontribusi yang signifikan dalam perkembangan astronomi klasik. Kehidupan manusia 
yang diikat dengan ruang dan waktu tentu sangat membutuhkan kehadiran sebuah instrumen. Astrolabe turut mewarnai aktivitas sehari-hari manusia dengan memainkan perannya sebagai instrumen yang berfungsi untuk menentukan waktu dengan berpatokan pada Matahari pada siang hari dan bintang pada malam hari. Astrolabe di samping sebagai penentu waktu, juga dimanfaatkan untuk menentukan musim. Fungsi tersebut sangat membantu manusia dalam bidang agraris yang menjadi mata pencaharian pokok pada masa kuno.

Kehadiran Astrolabe dalam dunia Islam sangat membantu dalam aktivitas ibadah. Fungsi utama Astrolabe sebagai penentu waktu satu tarikan napas dengan syariat Islam, karena Astrolabe berpatokan kepada Matahari. Sebagaimana diketahui, waktu masuknya lima salat fardu dalam literatur hukum Islam ditandai dengan fenomena alam, seperti tergelincirnya Matahari (zawāl) untuk salat zuhur dan bertambahnya bayangan Matahari untuk salat asar.

Fungsi Astrolabe secara umum, di antaranya mengetahui zodiak dan skala peredarannya, menentukan posisi Matahari dan bintang, mengetahui waktu (jam), menentukan waktu salat, menentukan waktu bayangan kiblat, mengetahui ketinggian suatu benda.

Salah satu fungsi Astrolabe dalam hisab adalah untuk menentukan waktu lokal Matahari terbenam. Misalnya, menentukan waktu terbenam Matahari pada tanggal 30 Oktober. Langkah-langkah yang harus ditempuh adalah sebagai berikut:

a. Tentukan posisi Matahari pada tanggal 30 Oktober. Caranya:

1. Putar aldide pada bagian belakang hingga menunjukkan 30 Oktober.

2. Lihat skala zodiak pada limb, yaitu Scorpio 6.

b. Menentukan waktu Matahari terbenam. Caranya:

1. Putar rete pada bagian depan Astrolabe sampai posisi Scorpio 6 hingga menyentuh ufuk (kanan).

2. Putar rule sampai bersentuhan dengan Scorpio 6. 
3. Lihat waktu yang ditunjukkan oleh rule pada limb. Itulah waktu terbenam. Pada contoh ini waktu terbenam Matahari jatuh pada 18:05 istiwa'.

Selain berfungsi untuk perhitungan, Astrolabe juga berfungsi untuk mengetahui tinggi Matahari bintang dengan pengamatan. Mengamati Matahari dengan Astrolabe dapat dilakukan dengan langkah:

a. Membidik Matahari dengan menggunakan alidade di bagian belakang Astrolabe.

b. Sinar Matahari dibidik dengan dua lubang pada alidade tersebut.

c. Setelah diketahui ketinggiannya, maka data tersebut bisa digunakan untuk menentukan waktu dengan cara meletakkan zodiak pada rete sesuai dengan ketinggian pada saat pengamatan kemudian memutar rule tepat pada zodiak tersebut dan lihatlah waktu yang ditunjukkan.

Jika pengamatan dilakukan pada malam hari, maka yang menjadi objek pengamatan adalah bintang. Pengamatan bintang dengan Astrolabe dilakukan dengan langkah-langkah berikut:

a. Kenali bintang yang akan dibidik.

b. Arahkan alidade pada bagian belakang Astrolabe ke objek tersebut.

c. Bidik bintang tersebut dengan menggunakan lubang pada alidade.

d. Jika berhasil dibidik, lihatlah ketinggian bintang tersebut pada limb.

e. Setelah diketahui ketinggiannya, putarlah rete sesuai dengan nama bintang yang dibidik dan arahkan pada angka ketinggian tersebut.

f. Kemudian putar rule hingga menyentuh nama bintang yang dibidik. Lihatlah waktu yang ditunjukkan rule pada limb.

\section{Kelebihan dan Kekurangan Astrolabe}

Astrolabe sebagai instrumen klasik mempunyai beberapa keunggulan, di antaranya alat ini berfungsi sebagai instrumen perhitungan sekaligus pengamatan. Astrolabe dalam fungsinya sebagai alat perhitungan tidak membutuhkan alat bantu lain, seperti untuk menghitung fungsi trigonometri, pada bagian belakang Astrolabe disediakan al-rub'u al- 
'alawi (kuadran sinus), zîl al-mabsūt (umbra recta) dan Zîl al-Mankūs (umbra versa).

Astrolabe juga mempunyai kekurangan, di antaranya Astrolabe dibuat dengan acuan waktu hakiki (solar time) dengan berdasarkan pada peredaran semu Matahari, sehingga skala waktu yang ditunjukkan oleh Astrolabe adalah waktu hakiki, bukan waktu daerah. Oleh sebab itu, masih diperlukan konversi waktu hakiki Matahari ke waktu daerah.

Pengoperasian rete antara Astrolabe yang dirancang untuk memproyeksikan langit Selatan dan langit Utara berbeda. Pada peta langit Utara, rete Astrolabe berputar dari kiri ke kanan (anti clockwise), sedangkan pada peta langit Selatan, rete Astrolabe berputar dari kanan ke kiri (clockwise).

Ketelitian Astrolabe tergantung kepada ukuran Astrolabe. Semakin besar ukuran Astrolabe, maka semakin tinggi pula tingkat akurasi data yang diperoleh dalam perhitungan maupun pengamatan. Kekurangan lain pada Astrolabe adalah pembacaan terhadap data sampai pada derajat, tidak mencakup menit dan detik.

\section{Penutup}

Astrolabe sebagai instrumen klasik dalam dunia astronomi sangat membantu manusia dalam melakukan aktivitas, karena fungsi utamanya adalah menentukan waktu dengan berpatokan pada perjalanan Matahari dan pengataman bintang pada malam hari. Astrolabe terus mengalami modifikasi dan perkembangan ketika instrumen klasik ini masuk dalam dunia Islam. Kehadiran Astrolabe dalam dunia Islam dimanfaatkan untuk keperluan ibadah, yaitu menentukan waktu salat. Pada perkembangan selanjutnya, Astrolabe dapat dimanfaatkan untuk menentukan waktu terjadinya rasd alqiblah. 


\section{DAFTAR PUSTAKA}

Butar-Butar, Arwin Juli Rakhmadi, Khazanah Astronomi Islam Abad Pertengahan, Purwokerto: $\quad$ UM Purwokerto Press, 2016.

Haji Khalifah, Kasyf al-Zunūn 'an Asāmi al-Kutub wa al-Funūn, Beirut: Dār Ihyā' al-Arabi, t.th.

Hayton, Darin, An Introduction to the Astrolabe, ebook.

Khālid, al-Usţurlāb,ebook.

al-Khawarizmi, Abu Abdillah Muhammad, Mafatih al-'Ulum, Beirut: Dar alManahil, 2008.

Morrison, James E., The Astrolabe, DE USA: Janus Rehoboth Beach, 2007.

Qulub, Siti Tatmainul, Ilmu Falak dari Sejarah ke Teori dan Aplikasi, Depok: PT RAJAGRAFINDO, 2017.

al-Saffar, Ibn, al- 'Amal bi al-Usţurlāb, Mesir: al-Ma'had al-Misri: 1955.

\section{Sumber Lain:}

King, David A., The Origin of The Astrolabe According to The Medieval Islamic Sources, Journal for the History of Arabic Science, Vol. 5, 1981.

Neugebauer, BY O., The Early History of The Astrolabe; Studies in Ancient Astronomy IX (1949), Journal Isis Chicago, doi: 10.1086/349045.

Wawancara dengan Mutoha Arkanuddin di kediamannya, Jl. Gejayan Suropandan Yogyakarta pada 28 Oktober 2018, pukul 21:00 WIB. 